\title{
Stages of the Environmental Risk Assessment
}

\author{
Monarkh Veronika Valentynivna ${ }^{1}$, Pantsyreva Hanna Vitaliivna²
}

\author{
${ }^{1}$ Candidate of Agricultural Sciences, Associate Professor of the Department of Landscape \\ Management, Forestry, Horticulture and Viniculture of Vinnytsia National Agrarian University (3, \\ Soniachna Str., Vinnytsia, Ukraine). Tel: +380977938424; ORCID 0000-0002-4473-7683 \\ ${ }^{2}$ Candidate of Agricultural Sciences, Senior Lecturer of the Department of Forestry, Horticulture, \\ Horticulture and Viticulture, Vinnytsia National Agrarian University (21008, Vinnytsia, Soniachna \\ Str.3). \\ E-mail: monarhinya@ukr.net
}

Received: 14.11.2019. Accepted: 05.12.2019

\begin{abstract}
The current condition of the former pesticide storages has been investigated and characterized. All pesticide storages of Kryzhopil region are in extremely poor condition and they contain substantial amounts of unknown mixtures of unusable pesticides, which are stored in bulk in $100 \%$ of pesticide storages being a powerful source of environmental pollution by toxicants of various chemical composition. Pesticide residues in different environment (soil, water, plant) have been determined. The research results clearly prove availability of severe local sources of contamination of agricultural lands with organochlorine pesticides. There is a risk of contamination of other environmental objects with hazardous substances and a negative impact of toxic substances on human health. Migration of pesticides from the soil into agricultural products and drinking water has been identified. It has been suggested that poor environmental conditions and consumption of pesticide-contaminated agricultural products and drinking water lead to an increase in the number of human diseases. It has been found that the population of the district has much higher morbidity rates compared to the indicators of the oblast. Step-by-step environmental risk assessment has been carried out.
\end{abstract}

Key words: Obsolete pesticides; Ecological risk; Mathematical model

\section{Introduction}

The current global ecological conditions are being constantly deteriorating due to the increase in the number of anthropogenic accidents and catastrophes, negative climate change, environmental pollution, especially with organic xenobiotics. Organic pollutants being of industrial, agricultural and consumer origin that are released into the environment in various ways get into agriecosystems. Among nearly 400 thousand names, 12 substances are considered to be especially dangerous and included in the Stockholm Convention on Persistent Organic Pollutants. Eight of twelve hazardous substances are the pesticides. Pesticide use is one of the tools for agri-ecosystem quality management. Application of pesticides and agrichemicals, soil tillage, capacity of the territory to get self-purified in the agri-ecosystem are related to the concept of environmental risks. Environmental risks are defined as potential treats that may have adverse effects on the environment [1-3]. International experience indicates that environmental pollutants that may be somewhat harmful and toxic to the population despite no carcinogenic properties have to be recorded [4-6]. Although numerous environmental factors do not lead to any changes, they can serve as a background that causes increased sensitivity to other simultaneous or later effects or alter the nature and severity of the pathological process [7]. Modern pesticides and unusable chemical pesticides are examples of chemical stressors, since they are constantly or periodically released into the environment and cause toxic effects. When a chemical (physical, biological) stressor appears, ecological risk assessment enables to determine potential changeable and unalterable effects on the ecosystem and to take preventive measures that would stop the adverse effects [8]. The risk assessment system consists of the steps that need to be taken in the process of environmental risk assessment for a variety of chemicals, both industrial chemicals and agrichemicals (including pesticides) $[9,10]$. This system is aimed to establish an objective risks in a particular area (including classification of risk factors and their possible effects), to provide quantitative risk assessments and damage to the human health and the environment.

\section{Materials and Methods}

The research was carried out on the territory of Kryzhopil region, Vinnytsia oblast. Analysis of the condition of pesticide storages was carried out on the basis of materials of the State Administration for Environmental Protection in Vinnytsia oblast as well as the results of the author's observations. Determination of pesticide residues in the soil, water and agricultural products within the limits of effects of former storages of unusable and forbidden pesticides was performed by HC-MS and HPLC-MC/MC methods using QuEChERS-method with the use of extraction, redistribution in acetonitrile and purification with dispersion TФE. The system 'Wolfram Mathematica 8 ' was used for mathematical calculations. 


\section{Result and Discussion}

Risk identification or Data collection and Evolution are the first step in the hazard assessment of pesticides. At this stage it is necessary to identify and formulate the problem. At the stage of hazard identification based on the research data, a potentially serious effect of pollutants on the environment is identified at a qualitative level through comparison of the natural conditions and similar chemical substances. According to official data, in Ukraine there is over 20,000t of obsolete, unusable and forbidden chemical plant protection products, much of which belong to organochlorine (OC) pesticides. Toxic chemicals are stored in 4,271 storages, which have not met the requirements for the technical and operational condition for a long time. Long-term use and mismanagement of pesticides has resulted in contamination of ecosystems at the place where pesticide storages having high concentrations of these compounds are located [11]. Former pesticide storage buildings located in 10 settlements of Kryzhopil region, Vinnytsia oblast have been examined. These storages were taken out of service in the 1980s and 1990s. All buildings tested contain residues of unusable and forbidden chemical plant protection products. Based on the examination of the inventory acts provided by the State Administration for Environmental Protection in Vinnytsia oblast, the current state of the former pesticide storage buildings has been characterized. This information is presented in Table 1.

Table 1. General characteristics of storage buildings for unusable pesticides in Kryzhopil region.

\begin{tabular}{|c|c|c|c|c|c|c|}
\hline 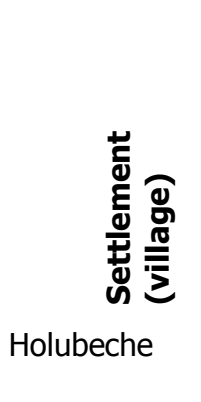 & 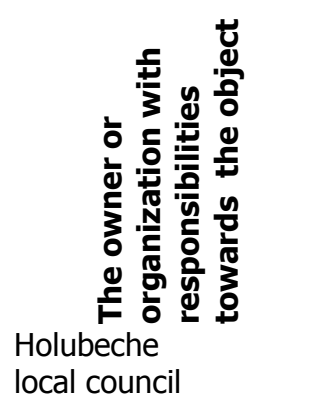 & 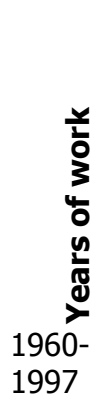 & 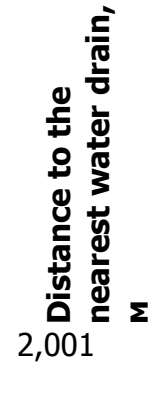 & 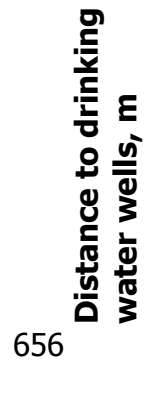 & 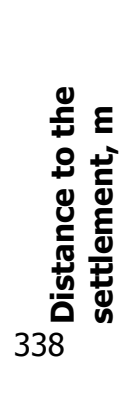 & 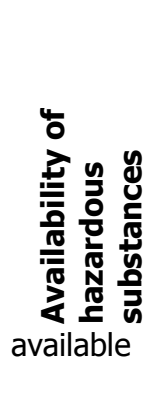 \\
\hline Leonivka & $\begin{array}{l}\text { Dzhuhastra } \\
\text { local council }\end{array}$ & $\begin{array}{l}1958- \\
1999\end{array}$ & 1,250 & 872 & 145 & available \\
\hline Hariachkivka & "Hariachkivske" ALLC & $\begin{array}{l}1956- \\
1985\end{array}$ & 1,200 & 5,001 & 320 & available \\
\hline Zelenianka & "Zelenianka" LLC & $\begin{array}{l}1965- \\
1988\end{array}$ & 830 & 830 & 290 & available \\
\hline Kisnytsia & $\begin{array}{l}\text { Kisnytsia } \\
\text { local council }\end{array}$ & $\begin{array}{l}1960- \\
1997\end{array}$ & 1,630 & 2,317 & 793 & available \\
\hline Radianske & $\begin{array}{l}\text { Holubeche } \\
\text { local council }\end{array}$ & $\begin{array}{l}1963- \\
1998\end{array}$ & 2,001 & 685 & 821 & available \\
\hline Kunyche & "Kunytske" ALLC & $\begin{array}{l}1967- \\
1985\end{array}$ & 951 & 5,001 & 535 & available \\
\hline Krasnosilka & $\begin{array}{l}\text { Krasnosilka } \\
\text { local council }\end{array}$ & $\begin{array}{l}1966- \\
1997\end{array}$ & 2,001 & 1,304 & 361 & available \\
\hline Sharapanivka & "Sharapanivka" LLC & $\begin{array}{l}1965- \\
1981\end{array}$ & 1,100 & 5,001 & 850 & available \\
\hline Andriiashivka & $\begin{array}{l}\text { Andriiashivka local } \\
\text { council }\end{array}$ & $\begin{array}{l}1964- \\
1986\end{array}$ & 1,850 & 1,430 & 943 & available \\
\hline
\end{tabular}

Storages for unusable pesticides in Kryzhopil region have the owner or the organization with responsibilities towards the object. All storages were built in the 60 's. The oldest one is the storage in Leonivka village of Dzhuhastra local council, which was built in 1958 and has been operating for almost 41 years. Thus, almost all storage buildings are half-destroyed, though it is not surprising due to their operation terms [12]. Insignificant distance of pesticide storages from drinking water wells in the villages of Holubeche and Radianske is dangerous. Such close proximity to water sources may pose a risk of water contamination by migrating toxic substances. The distance from the storage to the settlements, for all storages without exception, that is less than $1 \mathrm{~km}$ is dangerous as well. The closest to the settlement is the storage of Leonivka village $(145 \mathrm{~m})$, which is a gross violation of the construction and operation of such facilities. Based on this, it can be concluded that due to the small distance from the facilities examined to the water sources and settlements, the mixtures of pesticides that are still available in the storages are extremely dangerous both to the environment and the local population due to possible migration processes and unsatisfactory technical and operational condition of buildings. It should be noted that these storage buildings were not adapted for long-term storage of unusable pesticides. Based on the visual assessment, it has been found that none of the storages examined was fenced. There are no warning and prohibition signs. In the villages of Zelenianka, Holubeche and Hariachkivka, storage buildings are completely destroyed and the remains of pesticides are kept in the open air. Soils of the sanitary zone of the former pesticide storage in Zelenianka village have been allocated for the personal land use. Storage buildings in Kunyche and Holubeche are located within agricultural lands causing a real threat of crop contamination with residues of unusable pesticides. In Sharapanivka and Leonivka villages, roofs and walls are partially destroyed. Due to the lack of windows and doors, there is free access of the population, especially children, to hazardous waste. In Kunyche, Sharapanivka, Krasnosilka and Kisnytsia a significant number of unusable poisonous chemicals in torn bags and rusty holey barrels were found. All substances and materials stored in storage buildings are classified as group "B" - unknown mixtures due to the loss of labeling and mixing of pesticides throughout long-term period. Table 2 provides information on the amount of pesticides in the former storages for chemical plant protection products in accordance with the inventory of unusable pesticides in Kryzhopil region. 
Table 2. Availability of unusable pesticides in out-of-service storages of Kryzhopil region.

\begin{tabular}{|c|c|c|c|c|}
\hline \multirow{2}{*}{$\begin{array}{l}\text { Settlement } \\
\text { (village) }\end{array}$} & \multicolumn{3}{|c|}{$\begin{array}{l}\text { Amount of unusable pesticides at the beginning of } \\
\text { the reporting year, } t\end{array}$} & \multirow[t]{2}{*}{ Storage conditions } \\
\hline & & & & \\
\hline Leonivka & 0 & 1 & 1 & Piled up \\
\hline Andriiashivka & 0 & 0.7 & 0.7 & $-/ /-$ \\
\hline Zelenianka & 0 & 1.2 & 1.2 & $-/ /-$ \\
\hline Kisnytsia & 0 & 3 & 3 & $-/ /-$, bags \\
\hline Holubeche & 0 & 1.5 & 1.5 & $-/ /-$ \\
\hline Kunyche & 0.9 & 12.5 & 13.4 & $-/ /-$, barrels, bags \\
\hline Radianske & 0.5 & 5.5 & 6 & $-/ /-$, barrels \\
\hline Hariachkivka & 0 & 3 & 3 & $-/ /-$ \\
\hline Sharapanivka & 0.8 & 9.2 & 10 & $-/ /-$, bags, barrels \\
\hline Krasnosilka & 0 & 0.4 & 0.4 & $-/ /-$, bags \\
\hline Total & 2.2 & 38.0 & 40.2 & \\
\hline
\end{tabular}

Solid pesticide mixtures have been identified in all pesticide storages. The largest number of them has been found in the storages of Kunyche village (12.5 t), Sharapanivka (9.2 t), and Radianske (5.5 t). Liquid mixtures of pesticides are also available in the abovementioned settlements, in particular, $0.9 \mathrm{t}, 0.8 \mathrm{t}$, and $0.5 \mathrm{t}$, respectively. It can be assumed that the removal and disposal of unusable pesticides from the storage buildings of these settlements have not been carried out. Thus, all pesticide storages of Kryzhopil region are in an extremely unsatisfactory condition and they contain significant amounts of unknown mixtures of unusable pesticides, which are piled up in $100 \%$ of the storages being a powerful source of environmental pollution by toxicants of different chemical composition. In accordance with the second stage of the Exposure Assessment, the boundaries of the risk areas must be determined. In particular, it is necessary to consider the maximum possible amount of substances and set the geographical limits of exposure to a toxicant. One of the parameters for toxicant evaluation was its content in different environments (atmosphere, soil, water, plant, biota). In order to fulfil the second stage of environmental risk assessment and determine pesticide residues in different environments, the storages with the highest amount of unusable pesticides were selected for further research. Thus, according to the results of screening of pesticide residues in the soil around the pesticide storages, the residual amounts of organochlorine pesticides were detected in all soil samples [13]. In the soil samples taken at a distance of $1 \mathrm{~m}$ from the pesticide storages in Holubeche and Radaianske, the content of organochlorine pesticides did not exceed maximum allowable concentration (MAC), but it was higher than the background values for agricultural lands in Ukraine (Table 3).

Table 3. Content of organochlorine pesticides in the soils of sanitary zones of pesticide storages in the villages of Kryzhopil region, $\mathrm{mg} / \mathrm{kg}$ (1 $\mathrm{m}$ away from the storage).

\section{Content of organochlorine pesticides, $\mathbf{m g} / \mathbf{k g}$}

\begin{tabular}{|c|c|c|c|c|c|c|c|}
\hline $\begin{array}{l}\text { Organochlorine } \\
\text { pesticides }\end{array}$ & 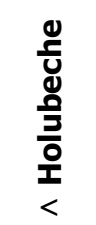 & 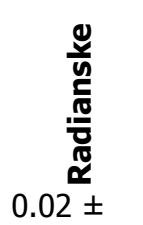 & $\frac{\frac{\pi}{y}}{\frac{5}{n}}$ & ำ & 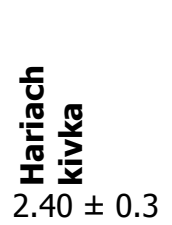 & 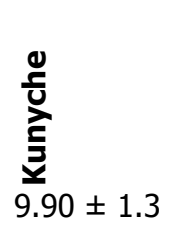 & 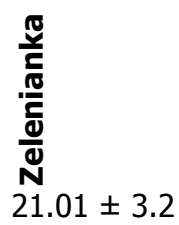 \\
\hline $4,4^{`}-\mathrm{DDE}$ & 0.01 & 0.01 & $0.12 \pm 0.05$ & $0.43 \pm 0.02$ & & & \\
\hline $4,4^{`}-\mathrm{DDD}$ & - & $<0.01$ & $0.1 \pm 0.01$ & $0.08 \pm 0.01$ & $6.4 \pm 1.1$ & $\begin{array}{l}20.30 \pm \\
2.9\end{array}$ & $22.10 \pm 3.4$ \\
\hline 4,4`-DDT & - & $<0.01$ & - & - & $5.10 \pm 0.4$ & $1.50 \pm 0.2$ & $1.02 \pm 0.2$ \\
\hline $2,4^{\prime}-\mathrm{DDD}$ & - & - & - & $0.05 \pm 0.01$ & - & $5.20 \pm 0.4$ & $10.00 \pm 1.3$ \\
\hline $2,4^{`}-\mathrm{DDE}$ & - & - & - & $0.04 \pm 0.01$ & - & $0.50 \pm 0.1$ & $0.90 \pm 0.1$ \\
\hline DDMU* & & & & & $5.75 \pm 0.8$ & $3.1 \pm 0.2$ & $3.6 \pm 0.3$ \\
\hline $\begin{array}{l}\text { The sum of } \\
\text { isomers and } \\
\text { metabolites of } \\
\text { DDT }\end{array}$ & $\begin{array}{l}< \\
0.01\end{array}$ & $\begin{array}{l}0.02 \pm \\
0.01\end{array}$ & $0.13 \pm 0.05$ & $0.6 \pm 0.02$ & $\begin{array}{l}19.65 \pm \\
1.1\end{array}$ & $40.5 \pm 2.9$ & $58.63 \pm 3.1$ \\
\hline $\mathrm{a}-\mathrm{HCH}$ & - & - & - & - & $0.32 \pm 0.1$ & $\begin{array}{l}0.03 \pm \\
0.01\end{array}$ & \\
\hline$\beta-\mathrm{HCH}$ & - & - & - & - & $\begin{array}{l}12.00 \pm \\
2.5\end{array}$ & $\begin{array}{l}0.50 \pm \\
0.1\end{array}$ & \\
\hline $\begin{array}{l}\text { The sum of } \\
\text { isomers of } \mathrm{HCH}\end{array}$ & - & - & - & - & $\begin{array}{l}12.32 \pm \\
2.5\end{array}$ & $0.53 \pm 0.1$ & \\
\hline MAC, $\mathbf{~ m g} / \mathbf{k g}$ & 0.1 & 0.1 & 0.1 & 0.1 & 0.1 & 0.1 & 0.1 \\
\hline
\end{tabular}

In the soil samples taken at a distance of $1 \mathrm{~m}$ from the pesticide storage in the sanitary zone in Kisnytsia, there was revealed the content of isomers and metabolites of OC pesticides at the rate of $1.3 \mathrm{MAC}$. In the soil of the sanitary zone of the pesticide storage in Leonivka sampled at a distance of $1 \mathrm{~m}$ from the storage, there was established 6 times exceedance of hygienic standards by the content of OC pesticides. 
In the soil samples taken within a radius of $1 \mathrm{~m}$ from the out-of-service storage of agrichemicals in Hariachkivka, the content of DDT isomers and metabolites was $19.65 \mathrm{mg} / \mathrm{kg}$ of soil, which exceeded the limit values 196 times. The percentage ration of isomers and metabolites in the soil of the sanitary zone of out-of-service storage of agrichemicals in Hariachkivka was calculated (Figure 1). The major part of it consists of metabolites 4.4 DDD (33\%), DDMU (29\%) and $4.4^{`}$ DDT (26\%), insignificant amount of $4.4^{`}$ DDE $(12 \%)$. Excessive contamination of the soil with the pesticide could result in inhibition of the microorganisms-destructors DDT as a result of pesticide accumulation in the non-metabolized state. The ratio of DDE: DDD is $1: 3$, which indicates aerobic mechanism of DDT transformation.

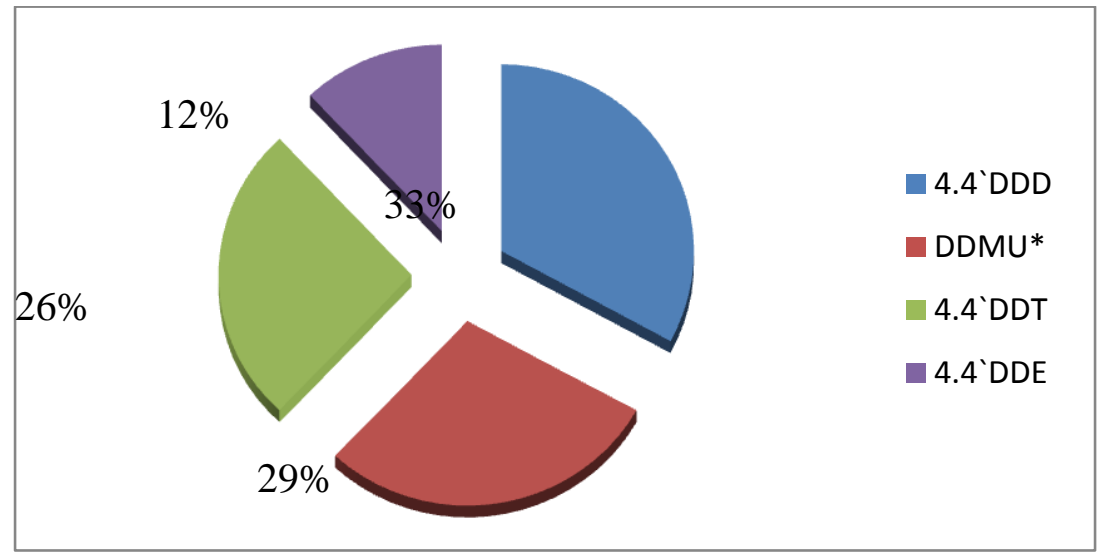

Figure 1. Percentage ratio of DDT isomers and metabolites in the soil of the sanitary zone of the out-of-service storage in Hariachkivka (1 $\mathrm{m}$ from the storage).

The content of hexachlorocyclohexane $(\mathrm{HCH})$ isomers in soil samples taken at a distance of $1 \mathrm{~m}$ from the storage shows an exceedance of maximum allowable concentrations: at a distance 123 times. The main part (97\%) is comprised by $\beta$-isomer $\mathrm{HCH}$, which proves that long time ago near-by territories were contaminated with $\mathrm{HCH}$. The results of analytical assessments clearly demonstrate that the content of DDT isomers and metabolites in the soil sampled within a radius of up to $1 \mathrm{~m}$ from the storage in Zelenianka exceeds hygiene standards 590 times $(58.63 \mathrm{mg} / \mathrm{kg})$. High content of non-metabolized $4.4^{`}$-DDT (1.02 mg/kg) in the soil indicates a strong toxic effect of pesticide contamination of the soil microbial coenosis involved in pesticide decomposition. However, availability of metabolites in the soil (4.4 $4^{`} \mathrm{DDD}$ and $4.4^{`} \mathrm{DEE}$ ) indicates the process of xenobiotic transformation.

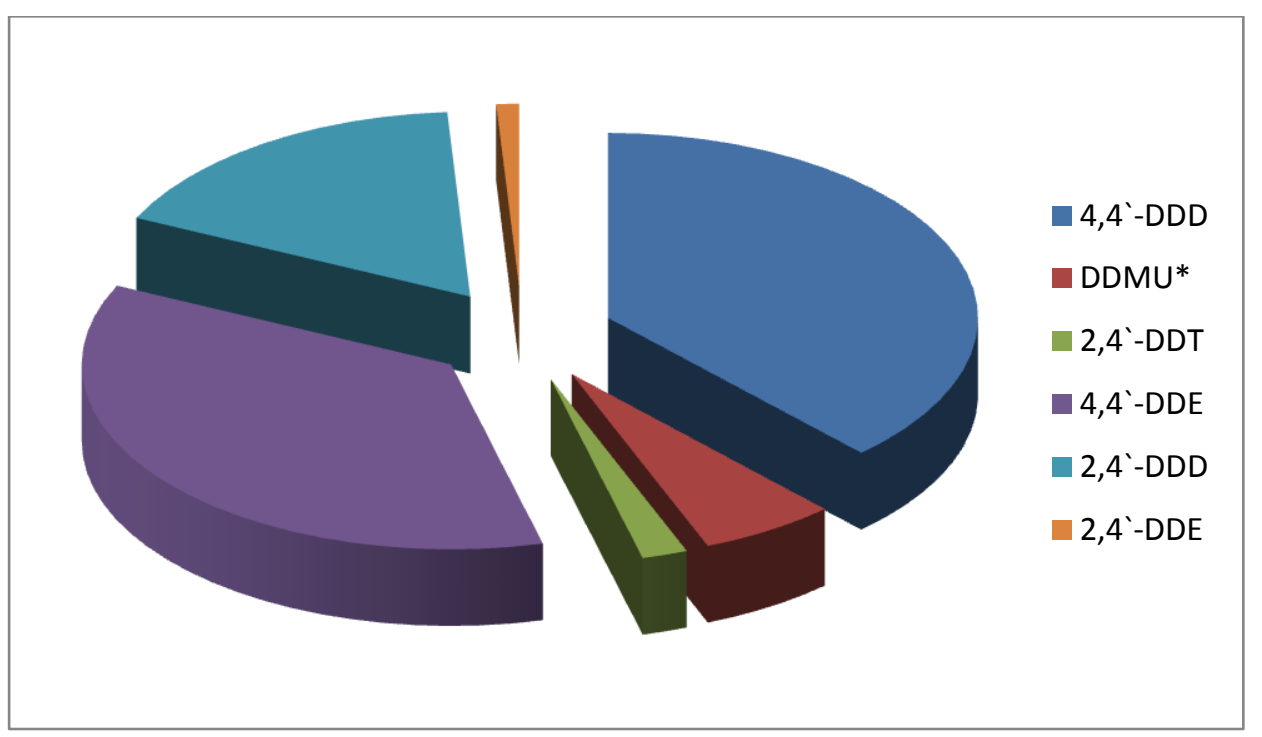

Figure 2. Percentage ratio of DDT isomers and metabolites in the soil of the sanitary zone of the out-of-service storage of agrichemicals in Zelenianka (1 $\mathrm{m}$ from the storage).

According to Figure 2, among the total number of DDT isomers and metabolites, the bulk are the most persistent metabolites of DDT: $4.4^{\prime}$-DDE (36\%) and 4.4 -DDD (38\%). The DDE: DDD ratio is $1: 1.5$ and indicates a predominantly anaerobic mechanism for DDT transformation $[14,15]$. The soil in the sanitary zone of the pesticide storage in Kunyche is heavily contaminated with organochlorine pesticides. At a distance of $1 \mathrm{~m}$ from the storage there were determined exceeded hygiene standards by the content of the amount of DDT isomers and metabolites at the rate of 405 MAC. This may indicate a toxic effect of high concentrations of xenobiotics on the soil microflora and the inhibited process of microbiological decomposition of toxic substances. Percentage of DDT isomers and metabolites in the soil of the sanitary zone of out-of-service storage of agrichemicals in Kunyche has been calculated (Figure 3). 


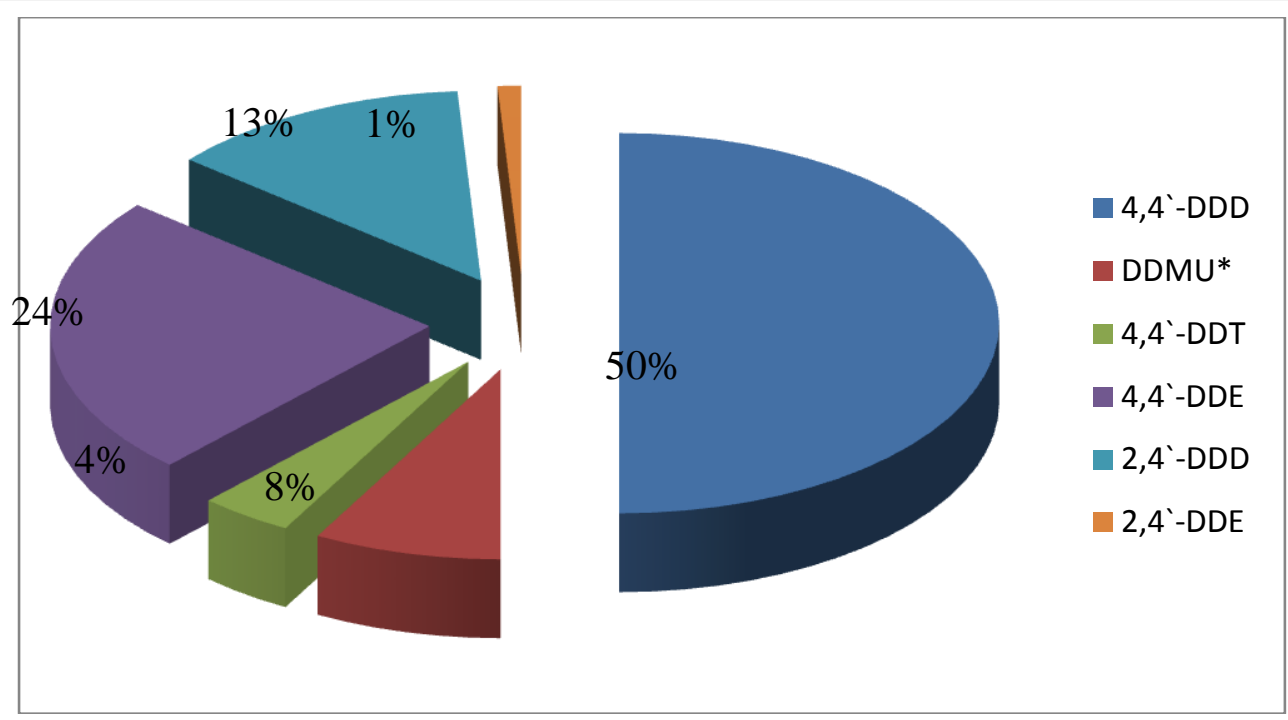

Figure 3. Percentage ratio of DDT isomers and metabolites in the soil of the sanitary zone of the out-of-service storage of agrichemicals in Kunyche (1 $\mathrm{m}$ away from the storage).

The major part is comprised by metabolites 4,4 $4^{`} \mathrm{DDD}(50 \%), 4.4^{`} \mathrm{DDE}(24 \%)$ and $2.4^{`} \mathrm{DDD}(13 \%)$, insignificant content of $2.4^{`} \mathrm{DDE}$ $(1 \%), 4.4^{`} \mathrm{DDT}(4 \%)$ and DDMU (8\%). This ratio of DDT isomers and metabolites indicates long-standing soil contamination with the pesticide. The process of secondary metabolism is quite slow, since the half-life of only $4.4^{\prime}$ DDE reaches about 190 years. The ratio of DDE: DDT is $1: 2.5$, which is characteristic of the aerobic mechanism of DDT transformation. In addition to large-scale soil contamination with DDT isomers and metabolites, residual amounts of $\mathrm{HCH}$ pesticide exceeding the established hygiene standards 5 times at a distance of $1 \mathrm{~m}$ from the pesticide storage have been found. $\beta-\mathrm{HCH}$, which is the isomer resistant to natural factors, accounts for $94 \%$ of the total amount of pesticide found. It can be assumed that for many years large amounts of OC pesticides have been stored in this storage. In addition to organochlorine pesticides in soil samples in Kunyche, found excess of hygienic standards for the content of triflusulfuron-methyl, carbendazim, prometrin, metalaxyl, metallochlor, trifluralin and lindane, $\mathrm{p}$. Zelenianka has identified excess of triadimephon content. The results of the studies are presented in Table 4 . According to the research results presented, in soil samples selected within the sanitary zone of the pesticide storags in Kunyche th content of triflusulfuron-methyl exceeds the established standards 3.7 times, carbendazim 3.5 times. To comply with the rules and technologies of pesticide application, soil contamination by the above-mentioned pesticides is not permissible. Therefore, it can be assumed that the soils studied have long-standing accumulation of pesticides.

Table 4. Content of pesticide residues in the soil of sanitary zones of out-of-servicee storages in Kryzhopil region.

\begin{tabular}{|c|c|c|c|}
\hline Settlement (village) & Active ingredient of the pesticide & $\begin{array}{l}\text { Content in the } \\
\text { soil, } \mathbf{~ m g / k g}\end{array}$ & MAC, $\mathbf{~ m g} / \mathbf{k g}$ \\
\hline \multirow[t]{7}{*}{ Kunyche } & Triflusulfuron-methyl & $0.37 \pm 0.1$ & 0.1 \\
\hline & Carbendazim & $0.35 \pm 0.1$ & 0.1 \\
\hline & Promethn & $0.50 \pm 0.1$ & 0.5 \\
\hline & Metalaxyl & $0.12 \pm 0.1$ & 0.05 \\
\hline & Metal chlorine & $0.18 \pm 0.1$ & 0.02 \\
\hline & Trifluralin & $11.03 \pm 2.4$ & 0.1 \\
\hline & Lindane & $0.86 \pm 0.1$ & 0.1 \\
\hline Zelenianka & Triadimephone & $1.30 \pm 0.2$ & 0.03 \\
\hline
\end{tabular}

All active substances of pesticides found are of Classes 2 and 3 and have a half-life in the soil of 3 to 400 days. Considering the fact that storage buildings have not been used for more than 20 years, availability of such substances in the soil undoubtedly testifies a severe long-standing contamination of the soil cover with pesticides, possible vertical migration of xenobiotics in the environmental objects. The content in the soil of edaphotop in the storage of residual amounts of lindane and chlorine is potentially hazardous. Exceedance of the maximum allowable concentrations of lindane by 8.6 and metal chlorine by 9 times is certainly a consequence of the long-standing soil contamination with organochlorine pesticides. Lindane-based products are not used in the EU, as the pesticide has long been prohibited for the application because of its negative properties (cumulative and carcinogenic). Water samples for the determination of pesticide residues were taken in Kunyche, Zelenianka and Hariachkivka, where previous studies have found significant exceedances of hygiene standards for pesticide content in the soil. 
According to the inventory, the storage in Zelenianka is located in the shortest way to the well of drinking water (830m). The storage in Hariachkivka is the farthest to the well of drinking water $(5,001 \mathrm{~m})$, however the distance to the settlement is only 320 $\mathrm{m}$. Water samples were taken in the nearest wells in the private households of the local population.

The research results (Table 5) show the availability of residues of a wide range of volatile substances of pesticides in the water samples. The vast majority of pesticide residues do not exceed established standards. However, water samples taken in Zelenianka identified the content of Prometrin and Acetochlor that excesses MAC.

Table 5. Content of pesticide residues in the water of wells in Kryzhopil region, mg/l.

\begin{tabular}{lllll}
\hline Active ingredient & \multicolumn{2}{l}{ Content of pesticides, mg/l } & & \multicolumn{1}{c}{$\begin{array}{l}\text { MAC in } \\
\text { drinking } \\
\text { water, mg/I }\end{array}$} \\
& Hariachkivka & Kunyche & Zelenianka & 0.002 \\
Acetochlor & 0.0002 & - & 0.048 & 0.002 \\
Prometrin & - & - & 0.009 & 0.02 \\
Spiroxamine & - & - & 0.0014 & 0.05 \\
Ethofumesate & - & - & 0.00016 & 0.02 \\
Metallachlor & - & - & 0.0095 & 0.002 \\
Chlorpyrifos & - & - & 0.000085 & 0.02 \\
Triadimephone & - & - & 0.0085 & 0.006 \\
Flutriafol & - & - & 0.0025 & 0.15 \\
Propiconazole & - & - & 0.00085 & n.s. \\
Piperonyl butoxide & 0.0007 & & - & \\
\hline Note:
\end{tabular}

Note: n.S. - Not Standardized.

The content of acetochlor is $0.048 \mathrm{mg} / \mathrm{l}$, which exceeds the established standards by 24 times. According to EU environmental organizations, the half-life of Acetochlor is 7-17 days in the field conditions, but manufacturers argue that the pesticide remains in the soil for 2-3 months. Considering the carcinogenicity and ecotoxicity of acetochlor, it is necessary to apply acetochlor-based products in agriculture with great caution and to control the pesticide residues in the environment [16]. Acetochlor is known to be moderately soluble and poorly degradable in water. The pesticide is very toxic to fish and dangerous for algae and aquatic organisms. Acetochlor toxicity significantly changes the composition of water microflora, leading to major changes in the aquatic ecosystem. In addition to the harm to aquatic organisms, the continued consumption of contaminated water can cause a number of undesirable effects on human health. The most common ones are cancer and thyroid diseases [14-16]. In addition to acetochlor, the content of promethrin in water has exceeded the concentration limit by 4 times. Prometrine's half-life is 14 to 316 days, so it can be argued that pesticide residues in water are the result of vertical migration from the contaminated soil. The danger to humans is that the systematic or permanent effect of prometrin on the organism causes disorders in the nervous system functions [16]. Availability of residues of active pesticide substances in water is of great concern, since most of them are characterized by poor water solubility and a moderate ability to migrate in the soil profile. Thus, spiroxamine is considered to be medium-toxic to humans and bees, but it is quite toxic to aquatic organisms. The process of pesticide accumulation and migration in the soil environment is the result of interaction of a number of factors, the main of which are physicochemical, agro-biological, microbiological properties of the soil, climatic conditions and, of course, chemical properties of the pesticide substance. Since the researched area is located in conditions that promote rapid metabolism of pesticides in the environment (sufficient amount of heat, moisture, proper humus availability in the soil, etc.), availability of pesticide residues in water indicates a long-term and substantial flow of toxicants into the soil with their migration into the water horizons. Taking into account a severe soil contamination with pesticide residues in the researched areas and the possibility of migration and bioaccumulation of toxicants in the chain 'soil - plant', the residual amounts of pesticides in the samples of plants grown on contaminated soils have been determined. The plant samples have been taken within the sanitary zones of the pesticide storages in Zelenianka, Kunyche, Hariachkivka, where previous studies have found the amounts of DDT isomers and metabolites in amounts that excessed MAC by 590, 405 and 196 times, respectively. The results of analytical studies are presented in Table 6.

Table 6. Content of OC pesticide residues in the agricultural products grown in Kryzhopil region.

\begin{tabular}{|c|c|c|c|c|}
\hline $\begin{array}{c}\text { Settlement } \\
\text { (village) }\end{array}$ & Crop & Pesticide & Content, mg/kg & MAC, $\mathbf{~ m g} / \mathbf{k g}$ \\
\hline \multirow{2}{*}{ Zelenianka } & \multirow{2}{*}{ Beta vulgaris } & $\begin{array}{l}4.4^{\prime}-\mathrm{DDE} \\
4.4^{\prime}-\mathrm{DDD} \\
2.4^{\prime}-\mathrm{DDT}\end{array}$ & $\begin{array}{c}0.34 \pm 0.1 \\
0.04 \pm 0.01 \\
0.04 \pm 0.01\end{array}$ & \multirow{2}{*}{0.1} \\
\hline & & $\Sigma \mathrm{DDT}$ & $0.42 \pm 0.1$ & \\
\hline $\begin{array}{c}\text { Kunyche } \\
\text { Hariachkivka }\end{array}$ & $\begin{array}{l}\text { soybean } \\
\text { corn }\end{array}$ & $\begin{array}{c}4.4^{`}-\mathrm{DDE} \\
-\end{array}$ & $\begin{array}{c}0.18 \pm 0.1 \\
-\end{array}$ & $\begin{array}{c}0.1 \\
-\end{array}$ \\
\hline
\end{tabular}

On the private site (Zelenianka) located on the territory of a former storage of chemical plant protection products there was revealed a substantial contamination of beet samples with organochlorine pesticide residues. The content of the sum of DDT isomers and metabolites was $0.42 \mathrm{mg} / \mathrm{kg}$, which was 4 times higher than the established hygiene standards. It is not excluded that agricultural plants contaminated with pesticides have been consumed by people for many years. Soybean samples taken in Kunyche on the farmlands located close to the pesticide storage building showed an increase in DDC by almost 2 times. However, since soybean samples were taken on the agricultural field that had a large area compared to the contaminated area, as a result of the "biological dilution" of the pesticide in the crop biomass, the total contamination of the commodity products with pesticides is likely to be insignificant. 
In spite of the preliminary results of studies on the content of pesticides in soil samples (Hariachkivka), no pesticide residues have been identified in corn samples grown on the contaminated soil. This fact may be explained by the poor ability of cereals to accumulate organochlorine pesticides. When growing root crops, crops of pumpkin and legume family on the same soil, significant contamination of biomass with toxic substances is possible due to the expressed ability of these plants for bio-accumulation of organochlorine pesticides. In the view of the established contamination of plant biomass by residues of CO pesticides, their content should be monitored annually. In Zelenianka, the territory, which was a part of the sanitary zone of the pesticide storage, should be withdrawn from the land use with subsequent remediation.

The obtained research results clearly prove availability of local sources of severe contamination with organochlorine pesticides of agricultural lands. Characteristic features of organochlorine compounds are their high toxicity, bioaccumulation ability and ability to migrate over long distances, so there is a risk of contamination of other environmental objects with hazardous substances and the negative impact of toxic substances on human health [17]. Toxicity Assessment is the third stage of environmental risk assessment. In the process of assessing the ways of the stressor's influence, the general scheme of the pollutant impact on the biota is considered. In addition, the direct effect of the toxicant on human health is investigated. All information gathered is quantified by computer calculations. Having conducting a comprehensive survey of the territories of Kryzhopil region, during which pesticide migration from the soil into agricultural products and drinking water have been found, we have made an assumption about the dependence of the increase in population morbidity in Kryzhopil region on the pesticide contamination.

For four years, the morbidity rates in the region have far exceeded the morbidity rates in the oblast (including the towns). Rural people who work in agriculture and live near agricultural lands (who comprise a larger part of the population of Kryzhopil region) are much more likely to be negatively affected by agrochemicals of all kinds than the urban population.

Figures of diseases of musculoskeletal system in the region are almost 2 times higher those in the oblast. In Kryzhopil region there is a systematic annual increase in the number of diseases of the endocrine system (diabetes, thyrotoxicosis), diseases of the digestive system (cholecystitis, cholangitis), tumors and blood disorders, which may be related to the effects of pesticide contamination.

It is proved that almost all types of pesticides cause pathologies in the cardiovascular system of the organism (blockage of vessels and their weakening). The table presented above indicates a large number of diseases associated with the circulatory system (hypertension, coronary artery disease, angina pectoris). These figures far exceed those of similar diseases in Vinnytsia oblast.

Among the total number of diseases, during the last 4 years, the population of Kryzhopil region was most often diagnosed with circulatory system diseases (37\%), respiratory diseases (20\%), diseases of the musculoskeletal system and diseases of the digestive system $(10 \%)$. The population of the region is more often affected by infectious diseases, skin diseases, dysfunction of the respiratory system, etc. The impact of pesticide contamination leads to allergic reactions, which quickly develop from short-term to chronic allergies. According to the analyzed data, the least in number in the region are the patients having diseases of the hematopoietic organs (3\%), tumors (3\%) and diseases of the nervous system (4\%).

Poor environmental conditions and consumption of pesticide-contaminated agricultural products and drinking water have led to an increase in the number of diseases. Compared to the figures on Vinnytsia oblast, the morbidity rate in Kryzhopil region is much higher. Therefore, the migration of pesticides from the soil into plants, surface water, groundwater, and atmospheric air leads to an increase in the pesticide load on the population and poses a real threat to its health.

Environmental risk management is the final step in a comprehensive and important process of environmental risk assessment aimed to reduce various rates of risks caused by environmental degradation. This stage involves seeking and identifying management measures on the reduction of risks and practical implementation of the most effective ones. It is compulsory to monitor the results of implementation [15].

One of the risk management tools is risk benchmarking, which is a process of comparing and ranking different types of risk. Comparative risk analysis aims to identify the most significant component of the aggregate risk and aims to help to allocate scarce resources optimally for implementation of environmental protection measures.

Risk value derived from the situational risk model has enabled us to identify the storages (sites), where special measures are needed to reduce and eliminate pollution. According to the gradation of the situational risk value, the risk value in Kisnytsia is low. Therefore, it is not necessary to propose soil purifying measures on this territory, since the former pesticide storage does not pose a threat to the environment. In Leonivka, Hariachkivka and Zelenianka, where the absolute risk value is highly hazardous and the soils of these territories are contaminated with persistent pesticides, soil restoration methods must be offered.

There are two ways of dealing with contaminated soils, namely, conservation and purification. Conservation requires high costs, and it is not always environmentally friendly, destroys soil structure and reduces its productivity. Preliminary calculations indicate the ability of pesticides to migrate in the soil profile up to a distance of $100 \mathrm{~m}$ from the storage (Hariachkivka and Zelenianka), so removal and disposal of contaminated soil layer from such sites is too expensive and impractical.

The safest and most inexpensive method of soil restoration is biological purification of anthropogenically disturbed areas by plants. Phytoremediation is a set of technologies based on the natural, physiological properties of plants to decontaminate soils polluted with metals or organic compounds. Phytoremediation is based on such methods as phytodegradation, phytoextraction, phytostabilization, phytotransformation and phytovolatility [18].

Phytoremediation technologies are being developed in two areas of research. The first one is related to the versatile characteristics of sites requiring remediation (it has already been done by us). The second area involves the selection of plants that are able to accumulate organic xenobiotics from the soil and sometimes even degrade them. In the world practice, plants of the Cucurbitaceae family are used to restore areas contaminated with persistent pesticides. Researches by the Institute of Agroecology and Environmental Management of the National Academy of Agrarian Sciences of Ukraine have established the ability of cultivated and wild plants to accumulate persistent pesticides effectively, which has made it possible to increase the range of plants that can be effectively used in phytoremediation technologies [19]. Within the sanitary protection zone of the former storage of agrochemicals in Zelenianka there are private lands and ownerless abandoned lands. Taking into account the preliminary data on contamination of soils, water and agricultural plants with pesticide residues, it will be most effective on this territory to remove the lands from common land use with further grassing with wild plants that are capable of phytoextraction and phytodegradation of toxic substances. This will help to purify the soil and improve the conditions for the germination of new plant species. Researches by scientists of IAP NAAS have made it possible to identify wild plant species, which are the most promising for phytostabilization and phytodegradation of xenobiotics of contaminated soils, namely: Xánthium strumárium, Taraxacum officinale, Artemisia vulgaris, rigeron canadensis L, Achillea millefolium, Daucus carota, Elytrigia repens L, Oenothera biennis L., Calamagrostis epigeios The main 
part of the plant species mentioned belongs to the families of asteraceae (Asteraceae) and cereals (Poaceae) [20]. For the disposal of plant phytomass contaminated with DDT, composting should be carried out to ensure conversion of organic solid waste into a stable, humorous product. Anaerobic composting promotes better biodegradation of organochlorine pesticides. The storage with unusable pesticides in Hariachkivka borders on the agricultural lands. Pesticide residues have not been detected in maize samples taken from this field. However, significant contamination of soil samples and migration of persistent pesticide residues up to $100 \mathrm{~m}$ away from the storage requires soil restoration. To purify this area, it is advisable to carry out remediation using cultivated plants. Scientists of IAP NAAS have established the ability of annual cultivated plants of barley, wheat, bean, courgette, pumpkin, soybean to absorb DDT from contaminated soil. Considering a significant number of DDT isomers and metabolites identified in the soil in Hariachkivka, among the above-mentioned agricultural plants, we recommend to use the plants of Cucurbitaceae family, which prevails over legumes and cereals in terms of phytoextraction capacity concerning DDT.

\section{Conclusion}

Plants should be cultivated in accordance with conventional technologies for their growing. To increase the inflow of xenobiotics to plants, it is effective to apply fertilizers at a dose of $N 60$ P90 K60. The recommended dose of fertilizers will promote a more efficient transfer of DDT from the soil to plants. Application of fertilizers in such rates according to [18-20] allows to increase pesticide absorption by $2.2-2.3$ times. As a result of the lack of technical capabilities for utilization of plants contaminated with OC pesticides through high-temperature incineration, the disposal of waste of contaminated phytomass is recommended to be performed by anaerobic composting. In Leonivka, the agricultural field is located close to the pesticide storage. Considering relatively small amount of pesticide residues in the soil and the small scale of contamination(compared to Zelenianka and Hariachkivka), to reduce ecological risks of contamination with organochlorine pesticides, it is suggest to refuse from the cultivation of crops that can actively absorb toxicants, e.g. root vegetables, pumpkins, legumes, when planning crop rotations; to saturate crop rotations with cereals characterized by low phytoextraction capacity regarding OC pesticides.

Thus, to manage risks caused by pesticides in agriecosystems, environmentally sound solutions for the soil restoration have been proposed, in particular, to introduce phytoremediation technologies.

\section{References}

Antoniou, M., Habib, M. E. M., Howard, C. V., Jennings, R. C., Leifert, C., Nodari, R. O. (2012). Teratogenic effects of glyphosatebased herbicides: divergence of regulatory decisions from scientific evidence. J Environ Anal Toxicol. S4: 006. doi: 10.4172/21610525.S4- 006

Moreno-Gonzalez, R., Leon, V. M. (2017). Presence and distribution of current- use pesticides in surface marine sediments from a Mediterranean coastal lagoon (SESpain). Environ Sci Pollut Res Int. 24:8033-8048. https://doi.org/10.1007/s11356-017-8456-0.

McKnight, U. S., Rasmussen, J. J., Kronvang, B., Binning, P. J., Bjerg, P. L. (2015). Sources, occurrence and predicted aquatic impact of legacy and contemporary pesticides in streams. Environ. Pollut. 200:64-76. https://doi.orq/10.1016/i.envpol.2015.02.015. Gilbert, N. (2016). Global biodiversity report warns pollinators are under threat. Nat. News https://doi.org/10.1038/nature.2016.19456.

Paoli, D., Giannandrea, F., Gallo, M., Turci, R., Cattaruzza, M. S., Lombardo, F. (2015). Exposure to polychlorinated biphenyls and hexachlorobenzene, semen quality and testicular cancer risk. J. Endocrinol. Invest. 38:745-752. https://doi.org/10.1007/s40618015-0251-5.

Park, M. G., Blitzer, E. J., Gibbs, J., Losey, J. E., Danforth, B. N. (2015). Negative effects of pesticides on wild bee communities can be buffered by landscape context. Proc. Biol. Sci. 282:20150299. https://doi.org/10.1098/rspb.2015.0299.

Portier, C. J., Armstrong, B. K., Baguley, B. C., Baur, X., Belyaev, I., Belle, R. (2016). Differences in the carcinogenic evaluation of glyphosate between the International Agency for Research on Cancer (IARC) and the European Food Safety Authority (EFSA). J. Epidemiol. Community Health. https://doi.org/10.1136/jech-2015-207005.

Fairbrother, A., Burton, G. A., Klaine, S. J, Powell, D. E, Staples, C. A, Mihaich, E. M, Woodburn, K. B, Gobas, F. A. (2015). Characterization of ecological risks from environmental releases of decamethylcyclopentasiloxane (D5). Environ Toxicol Chem. Dec;34(12):2715-22. Epub Jul 24.doi: 10.1002/etc.3041.

Gobas, F. A., Kozerski, Xu. S., Powell, G., Woodburn, D. E., Mackay, K. B., Fairbrother, D. (2015). Fugacity and activity analysis of the bioaccumulation and environmental risks of decamethylcyclopentasiloxane (D5). Environ Toxicol Chem. 34(12):2723-31. doi: 10.1002/etc.2942. Epub 2015 Jul 24. PMID:26211424

Sanvido, O., Romeis, J., Gathmannb, A., Gielkensc, M., Raybouldd, A., Bigler, F. (2012). Evaluating environmental risks of genetically modified crops: ecological harm criteria for regulatory decision-making. Environmental Science \& Policy. V.15(1) p. 82-91 https://doi.org/10.1016/j.envsci.2011.08.006

Monarkh, V. V. (2014). Assessment of environmental risks of pesticide contamination of agroecosystem components. Balanced Nature Management. 1: 206-212.

Mokliachuk, L. I., Baranov, Y. S., Horodyska, I. M., Monarkh, V. V., Bilous, A. O. (2012). Storages for unusable and forbidden chemical plant protection products as a source of environmental hazards. Collection of scientific works of VNAU. Series Agricultural sciences. 1 (57)65-69.

Mokliachuk, L. I., Horodyska, I. M., Monarkh, V.V. (2012). The need for ecotoxicological evaluation of pesticide assortment in chemical crop protection. Bulletin of ZhNAU. 1. Access mode: http://www.znau.edu.ua/visnik/2012 1 1/232.pdf

Horodyska, I. M., Monarkh, V. V., Mokliachuk, T. O. (2013). Environmental risks of contamination of agricultural products with unusable pesticides. Balanced Nature Management. 4: 17-22.

Monarkh, V. V. (2014) Analysis of the status of former pesticide storages in Kryzhopil region of Vinnytsia oblast. Collection of scientific works of VNAU. Series Agricultural sciences. 5 (82)206-216.

Monarkh, V. V. (2017). Improvement of the system of ecotoxicological monitoring of pesticides through assessment of environmental risks. Collection of scientific works of VNAU. Series Agricultural sciences. 6:134-140.

Mokliachuk L., Drebot O., Mokliachuk O., Mokliachuk T., Monarkh V. (2014). Ecological risks from contamination of Ukrainian soils by persistent organic pollutants. Environment and Ecology Research. No. 2 (1). P. 27-34.

Petryshina V. (2009). Agroecological substantiation of phytoremediation capacity of wild plant species: abstract. diss. for the degree of Cand. Agricultural Sciences: Special. 03.00.16 Ecology. K. 22. 
Slobodenyuk O. (2008). Phytoremediation of soils contaminated with persistent organochlorine pesticides: abstract. diss. for the degree of Cand. Agricultural Sciences: Special. 03.00.16 Ecology. K. 20.

Zatsarinna Y. (2012). Ecological substantiate on of phytoremediation of soils contaminated with trifluralin: author. diss. for the degree of Cand. biol. Sciences: Special. 03.00.16 Ecology. K.20.

\section{Citation:}

Monarkh Veronika Valentynivna, Pantsyreva Hanna Vitaliivna. (2019). Stages of the Environmental Risk Assessment. Ukrainian Journal of Ecology, 9(4), 484-492. 